\title{
AN UNUSUAL NEW SPECIES OF HELMIOPSIS H. PERRIER (STERCULIACEAE) FROM MADAGASCAR
}

Eight species of Helmiopsis H. Perrier (Sterculiaceae) currently are recognized in the Flore de Madagascar et des Comores (Arènes, 1959). All are characterized by monodelphous androecia with staminodes opposite the petals, sessile ovaries, caducous petals, capsular fruits with apically winged seeds, and overall vestitures of peltate or fimbriate (i.e., peltate with fimbriate margins) scales. All species described to date are restricted to western Madagascar. A new species of Helmiopsis is described here from the northern mountains of Madagascar, also part of the phytogeographical Domaine de l'Ouest of the island (Humbert, 1965). This species combines several features that are unusual for the genus. For example, its spheroid, rather than conical, capsule morphology is unique and provides the basis for the name Helmiopsis sphaerocarpa $\mathrm{L}$. Barnett. The seed wings of $H$. sphaerocarpa are atypical for the genus in being reduced to only a thin, ventral keel; ordinarily seed wings of $\mathrm{Hel}$ miopsis species are apical and elongate, to $10 \mathrm{~mm}$ in length. The inflorescence is complex in structure, being multibranched and many-flowered, as opposed to the few-flowered cymose inflorescences more commonly found in the genus. The terminal nature of the inflorescence is also unusual in this species, although terminal inflorescences also have been observed in isolated collections of $H$. pseudopopulus (Baillon) Capuron (e.g., Capuron 24661, P). Finally, this new species is unique in bearing glandular tissue both on the calyx lobes and on the petals; in all other $\mathrm{Hel}$ miopsis species with glandular tissue, the tissue is restricted to either the calyx or the corolla, but is never found in both perianth whorls.

Helmiopsis sphaerocarpa L. Barnett, sp. nov. TYPE: Madagascar: Centre (Nord) jusqu'aux confins de l'Ouest (Nord), Massif de la Montagne d'Ambre, crête entre les bassins de la rivière des Makis et de la rivière d'Ankazobe, entre 800 et $600 \mathrm{~m}$ d'alt., 26-27 May 1970 (fl), Capuron 29194 SF (holotype, P; isotype, TEF). Figure 1.

Arbuscula vel arbor, squamarum lepidotarum deciduarum vestita. Folia late ovata vel anguste obovata, cordata, palmatim 5(-7) nervata. Inflorescentiae axillares et terminales, 15-30 floribus. Calyx 5-partita, lobis intus glandulosis. Petala 5, intus glandulosa. Tubus staminalis $1 \mathrm{~mm}$ altus; staminibus 10 , staminodiis 5 . Ovarium 5-loculare, loculis 2-ovulatis; stylo glabrato, stigmate leviter 5-lobata. Capsula sphaerica, loculicida. Semen carina ventrale membranacea.

Large shrub or tree to 8-12 $\mathrm{m}$ tall, branches terete, finely striate, new growth sparsely peltatescaled, older twigs glabrate. Leaves alternate, deciduous, blades broadly ovate to narrowly obovate, $6.5-12 \mathrm{~cm}$ long, 4-9 $\mathrm{cm}$ wide, apex acute to acuminate, base shallowly cordate to cordate, palmately $5(-7)$ nerved, midvein and secondary veins conspicuous, raised below and slightly depressed above, discolorous, margins irregularly crenulate, lower surface with scattered peltate and fimbriate scales, becoming glabrate; petioles 1$6 \mathrm{~cm}$ long, with scattered peltate and fimbriate scales. Inflorescences terminal and in the axils of uppermost 3-5 leaves, determinate, branching 3-5 times, bearing 15-30 flowers. Floral buds ovoid, 4-5 mm long, 4-4.5 $\mathrm{mm}$ wide. Calyx 5 -lobed, lobes connate only at the bases, lanceolate, ca. $7 \mathrm{~mm}$ long, $3 \mathrm{~mm}$ wide, outer surfaces densely covered with peltate scales, inner surfaces glabrate and with an arc of glandular tissue at the base. Petals 5, white (according to label data of Capuron 29194 SF), obovate, asymmetrical, 7-8 $\mathrm{mm}$ long and $7 \mathrm{~mm}$ wide, inner surface gland-dotted toward the base. Androecium coroniform, staminal column ca. $1 \mathrm{~mm}$ tall; stamens 10 , ca. $3 \mathrm{~mm}$ long from the base of the column, each of the 5 antisepalous pairs alternating with a staminode; filaments $1-1.5 \mathrm{~mm}$ long; anthers ca. $2 \mathrm{~mm}$ long; staminodes 5 , oblanceolate, 4-5 mm long, ca. $1 \mathrm{~mm}$ wide. Ovary 5 -locular, densely peltate-scaled; ovules 2 per locule, collateral; style 5-6 $\mathrm{mm}$ tall, glabrate; stigma obscurely 5 -lobed. Fruit capsular, woody, spheroid, dorsally loculicidal, 6-8 $\mathrm{mm}$ long, 8$10 \mathrm{~mm}$ wide, subtended by a woody, persistent calyx. Seeds 2 per carpel, asymmetrically ovate and laterally flattened, 5-6 mm long, 3-4 mm wide, each with a narrow, membranous, ventral keel.

Additional specimens examined. MAdAgascar. NORTHERN SECTOR. DISTRICT DIÉGO-SUAREZ: Versant Est du massif de l'Ankerana, 17 Dec. 1966 (fr), Capuron 27349 SF (P, TEF); Montagne des Français, 11 Sept. 1952 (fr), Service Forestier 5673 SF (P, TEF); Ambalafary, Ambodipo-Antsahalalina, 7 June 1956 (fl), Service Forestier 15962 SF (P, TEF). 


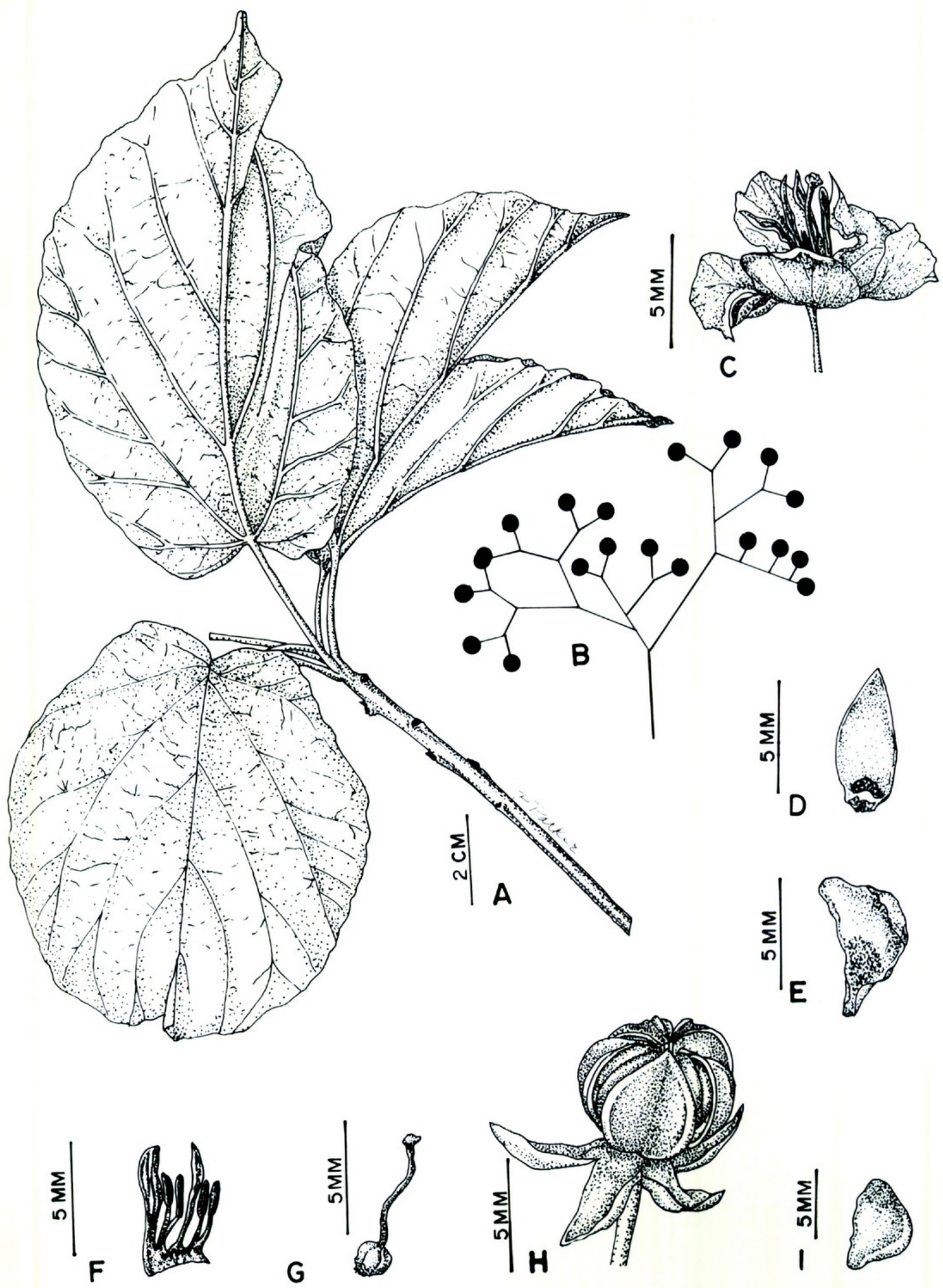

Figure 1. A-I. Helmiopsis sphaerocarpa.-A. Twig.-B. Schematic diagram of an inflorescence axis. -C. Flower. - D. Inner surface of calyx lobe showing glandular tissue. - E. Inner surface of petal showing glandular tissue.-F. Detail of the androecium.-G. Gynoecium.-H. Fruit.-I. Seed. (A, B. Capuron 27349 SF; C-G. Capuron 29194 SF; H, I. Service Forestier 5673 SF.) 
Helmiopsis sphaerocarpa occurs on mountain slopes between 50 and $800 \mathrm{~m}$ altitude. It has been reported on black volcanic soils, but its presence on the Montagne des Français suggests that it also may occur on limestone (Lemoine, 1906).

The 5-carpellate gynoecium and reduced stigmata of Helmiopsis sphaerocarpa place this species in Helmiopsis subg. Helmiopsis. Its broadly ovate leaves, glandular petals, and ten stamens ally it with sect. Glandulipetalae Arènes in subg. Helmiopsis. Helmiopsis pseudopopulus (Baillon) Capuron, a member of the same section, may be the most closely related species; it also has a many-flowered inflorescence, occasionally with a terminal axis. Glandular tissue at the base of the calyx, however, has been observed in only one other Helmiopsis species, $H$. inversa H. Perrier (sect. Helmiopsis).

This research was supported by NSF Doctoral Dissertation Improvement Grant BSR-8414032. I thank the curator of $\mathrm{P}$ for the loan of specimens, and of TEF for permission to examine material.
The illustration was prepared by P. Parker. L. Dorr and B. Stein provided helpful comments on the manuscript. Work in Madagascar was made possible by collaboration between the Missouri Botanical Garden and the Parc de Tsimbazaza, Antananarivo, Madagascar.

\section{Literature Cited}

AR ÈNES, J. 1959. 131e Famille-Sterculiacées. In $\mathrm{H}$. Humbert (editor), Flore de Madagascar et des Comores. Mus. Nat. Hist. Nat., Phanérogamie, Paris. Humbert, H. 1965. Description des types de végétation. In H. Humbert \& G. Cours Darne (editors), Notice de la carte, Madagascar. Section Scientifique et Technique de l'Institut Français de Pondichéry, Pondichéry, India.

Lemoine, P. 1906. Études géologiques dans le nord de Madagascar. Librairie Scientifique A. Hermann, Paris.

-Lisa C. Barnett, Department of Botany, University of Texas at Austin, Austin, Texas 787137640, U.S.A. 


\section{$2 \mathrm{BHL}$ Biodiversity Heritage Library}

Barnett, Lisa C. 1987. "An Unusual New Species of Helmiopsis H. Perrier (Sterculiaceae) From Madagascar." Annals of the Missouri Botanical Garden 74, 450-452. https://doi.org/10.2307/2399423.

View This Item Online: https://www.biodiversitylibrary.org/item/87376

DOI: https://doi.org/10.2307/2399423

Permalink: https://www.biodiversitylibrary.org/partpdf/19321

\section{Holding Institution}

Missouri Botanical Garden, Peter H. Raven Library

\section{Sponsored by}

Missouri Botanical Garden

\section{Copyright \& Reuse}

Copyright Status: In copyright. Digitized with the permission of the rights holder.

License: http://creativecommons.org/licenses/by-nc-sa/3.0/

Rights: https://biodiversitylibrary.org/permissions

This document was created from content at the Biodiversity Heritage Library, the world's largest open access digital library for biodiversity literature and archives. Visit BHL at https://www.biodiversitylibrary.org. 